\title{
Pilot study assessing the effect of Fascial Manipulation on fascial densifications and associated pain
}

\author{
Emmett Hughes (1), Jessica M. Koenig (2), Robert S. Lee (3), Kena McDermott (1), Tina \\ Freilicher (4), Mark H. Pitcher (4) \\ (1) School of Chiropractic, College of Health Sciences, University of Bridgeport, CT, USA; (2) \\ Vascular Laboratory, Department of Surgery, Northport VA Medical Center, Northport, NY, \\ USA; (3) Well Integrative Care Chiropractic, Acupuncture \& Rehabilitation, Syosset, NY, USA; \\ (4) College of Health Sciences, University of Bridgeport, Bridgeport, CT, USA.
}

This article is distributed under the terms of the Creative Commons Attribution Noncommercial License (CC BY-NC 4.0) which permits any noncommercial use, distribution, and reproduction in any medium, provided the original author(s) and source are credited.

\begin{abstract}
We assessed effectiveness of Fascial Manipulation (FM) in reducing densification thickness and associated acute pain in normal humans. Fascial densifications were identified using palpation and measured with diagnostic ultrasound within self-reported painful somatic regions. Pain intensity ratings were obtained in response to deep palpation of the self-reported painful somatic region before and after a brief FM intervention. Brief FM resulted in reduced densification thickness as well pain intensity. Sex differences were found neither in densification thickness nor pain intensity at any time point. However, a statistically significant positive correlation between densification thickness and pain intensity was observed in females but not males at both pre-FM and post-FM time points. As such, FM may be an effective therapeutic approach for acute pain associated with fascial densifications. While males and females exhibited comparable densification thickness and pain intensity levels at both pre-FM and post-FM time points, only females showed a statistically significant relationship between pain and densification, suggesting that females may be better able to perceive subtle differences in the magnitude of noxious sensory input.
\end{abstract}

Key Words: Fascial manipulation; pain; densification; sex differences; diagnostic ultrasound.

Eur J Transl Myol 32 (1): 10369, 2022 doi: 10.4081/ejtm.2022.10369

The fascial system is receiving increasing attention from a pain management perspective. Indeed, numerous studies demonstrate reduced pain and improved function following manual therapeutic intervention targeting fascia. ${ }^{1,2,3,4}$ There have been many descriptions of fascia, rendering it a less precise term. It has been described in histology texts as a dense, irregular connective tissue. A more modern description describes it as "the soft tissue component of the connective tissue system that permeates the human body forming a whole-body continuous three-dimensional matrix of structural support. ${ }^{5}$ Indeed, made up of loose connective tissue interposed between collagen sheets, the fascia surrounds and supports virtually every structure in the body, including muscles, tendons, ligaments, bone, nerves, blood and lymph vessels, and internal organs. Fascia is heavily invested in mechanoreceptors and contributes to local coordination of movement. ${ }^{6,7,8}$ As such, fascia appears to maintain the integrity of these structures, and has been proposed to serve as a network for information exchange due to its extensive interconnectivity throughout the body. ${ }^{9}$ Pathological alterations in fascia that cause pain include fibrosis and densifications. However, these two terms are not interchangeable, but rather describe two different phenomena. Fibrosis is the excess deposition of collagen, changing the architecture of the extracellular matrix and permanently altering the function. Densification refers to the thickening of the loose connective tissue layer present between the collagenous sheets within the fascia and can be reversed using manual therapies and hyaluronidase injections. ${ }^{2,10}$ Over the last decade, various groups have demonstrated that densifications within the fascial system can contribute to pain and fascial dysfunction. ${ }^{10-13}$ One research group has suggested that polymerization of hyaluronic acid (HA) within the fascial tissue may interfere with proper glide of the fascial layers. ${ }^{14,15,16}$ Recent research from our group showed that densifications within fascial tissue appear to be highly enriched in HA. ${ }^{17}$ Moreover, given that Cowman et al. ${ }^{14}$ suggested that local increases in temperature may 
decrease viscosity of polymerized HA, painful densifications within the fascial system could be treated by increasing heat using manual therapeutic interventions directed to the somatic location of interest. Fascial Manipulation (FM) is a relatively recent manual therapy approach that involves repetitive back and forth manipulations over specific fascial foci that produce deep mechanical forces and localized temperature increases. ${ }^{18}$ A number of studies have shown that FM is effective in reducing pain associated with various pain conditions, including low back pain, ${ }^{19,20}$ knee pain, ${ }^{3}$ elbow pain, ${ }^{21}$ temporomandibular joint pain, ${ }^{22}$ and ankle pain following a sprain. ${ }^{23}$ In the study described here, we hypothesized that FM may reduce musculoskeletal pain associated with clinically defined fascial densifications in normal, healthy adults. Moreover, given that ultrasound can be used to visualize perceived changes in fascial structure and function following manual therapy techniques, ${ }^{24}$ we hypothesized that FM would also decrease the thickness of densifications as measured by diagnostic ultrasonographic techniques.

\section{Materials and Methods}

\section{Study design and participants}

This study was approved by the Institutional Review Board at the University of Bridgeport. Federal regulations on the ethics of human research were strictly followed and written informed consent was obtained from each subject. Subjects were a convenience sample of healthy individuals, recruited from the University of Bridgeport School of Chiropractic student body and the University of Bridgeport Health Sciences Outpatient Clinic. Pamphlets advertising the study were placed on bulletin boards and announcements were also made in classes. A total of 42 subjects, 15 females and 27 males, were recruited.

\section{Experimental procedure}

The FM intervention was performed in a private treatment room in the university outpatient clinic. The investigator, an experienced chiropractor and Fascial Manipulation Stecco Method ${ }^{\circledR}$ practitioner, briefly described the goals of the study and asked subjects if they had stiffness or pain in any locations. Once a target region was identified, the investigator palpated the specified

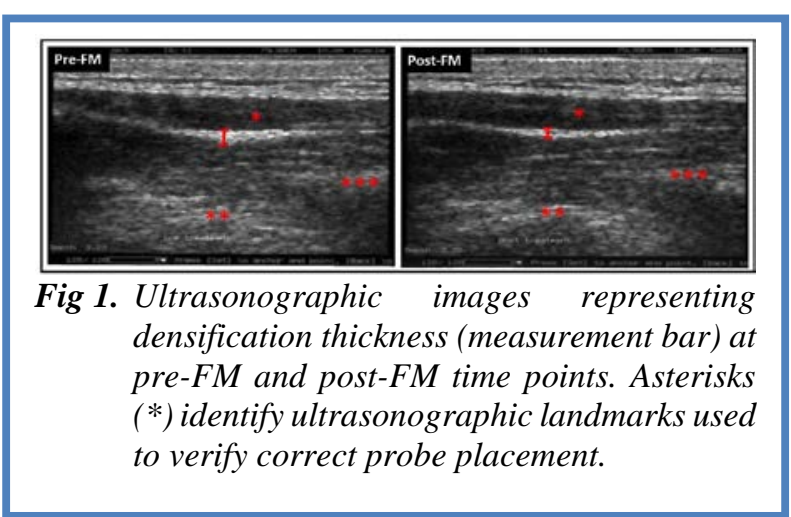

region directly on the skin to identify a densified center of coordination (CC). A center of coordination (CC) is defined as an area on the epimysial fascia where the vectors of force exerted by muscles converge to effect movement in a specific plane. ${ }^{25}$ The subjects were either seated or lying down, depending on the location of the target densified CC. A densification is operationally defined as a perceived localized thickening of the fascial tissue along with a lack of glide of the fascia upon palpation..$^{9}$ Palpation consisted of deep pressure with oscillation over the fascial tissue using elbows, knuckles and/or digits in a manner that normally does not evoke pain in non-densified CC. Once a densification was located, the skin directly above was marked with an " $\mathrm{X}$ " using a china marker pencil. The investigator then asked the subject to mark a line on a $15 \mathrm{~cm}$ visual analogue scale (VAS) that corresponded to the perceived pain intensity in response to the gentle palpation of the densification. Ultrasound imaging of the densified region was performed (see Ultrasonography methodology section below). Following ultrasound imaging, the investigator performed the brief FM intervention, consisting of 30-45 seconds of deep, oscillating pressure over the densification. Immediately after, the thickness of the area of densification was measured a second time using diagnostic ultrasound, and the subjects' second perceived pain rating was obtained, again following palpation. The entire procedure spanned approximately 15-20 minutes per subject. All data was collected over two consecutive days.

\section{Ultrasonography}

A Mindray DP-6600 diagnostic ultrasound machine was used to image and measure the thickness of the fascia at the densification. The ultrasonographer, an author on this paper (JMK), is a certified Registered Diagnostic Medical Sonographer (RDMS), Registered Diagnostic Cardiac Sonographer (RDCS) and Registered Vascular Technologist (RVT). Somatic ultrasound probe placement location was identified using the ' $\mathrm{X}$ ' drawn on the skin, as described above. The precise location for post-FM ultrasound image acquisition involved the matching of landmarks identified in the pre-FM ultrasound images (Figure 1). Thickness of densifications identified in the ultrasound images were measured offline

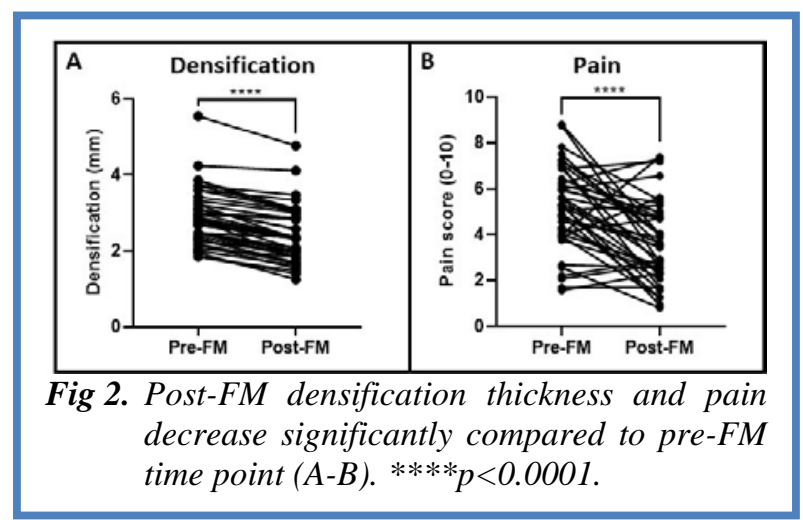




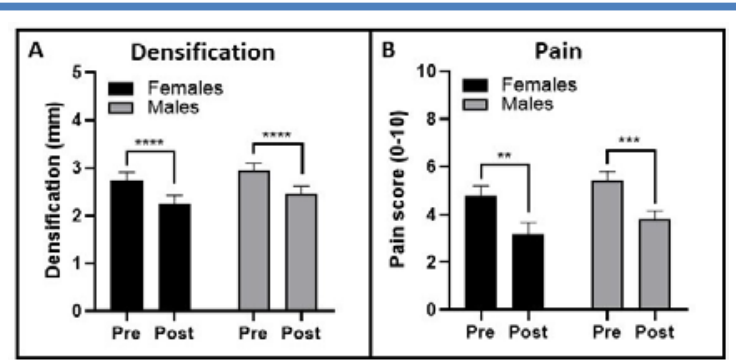

Fig 3. While significant main effects for time (PreFM vs. Post-FM time points) were found, no sex-dependent effects on densification thickness or pain ratings were observed (AB). ${ }^{* *} p<0.01,{ }^{* * *} p<0.001,{ }^{* * * *} p<0.0001$.

(after the experiment) by a trained ultrasonographer, using an integrated measurement tool providing point-topoint distance measurements in millimeters $(\mathrm{mm})$. Thickness was measured from the top edge to the bottom edge of the fascial sheet, at the thickest point of the identified densification (Figure 1).

\section{Statistical analysis}

All statistical analyses were performed with GraphPad Prism (V8.3.0). Paired-samples t-test, two-way mixedmodel analysis of variance (ANOVA), chi square $\left(\chi^{2}\right)$ and Pearson correlations were used, where indicated. In all cases, $p<0.05$ was considered significant.

\section{Results}

In all subjects, the densification thickness was significantly decreased after the FM intervention $(\mathrm{t}(82)=14.13 ; \quad p<0.0001 ;$ Figure 2A, Table 1). Specifically, mean thickness decreased by $16.71 \%$ from $2.87+/-0.11 \mathrm{~mm}$ to $2.39+/-0.11 \mathrm{~mm}$. The mean decrease in pain scores from the pre-FM (baseline) to the post-FM measurements was also significantly reduced $(\mathrm{t}(41)=5.174 ; p<0.0001)$ by $30.83 \%$, from $5.21+/-0.28$ to $3.60+/-0.27$ VAS units (Figure 2B, Table 1). A total of 31 of the 42 subjects reported decreased pain following FM (78.6\%); the rest indicated either no change or an increase in reported pain. Given that sex differences in pain perception is a well-described phenomenon, ${ }^{26-30}$ we assessed how sex impacted perceived pain and densification thickness in our sample. As aforementioned, while the majority of subjects (i.e. 31 of the 42 subjects) reported decreased pain following FM, the remaining 11 subjects reported no change or an increase in pain. As such, we used chi square $\left(\chi^{2}\right)$ analysis to determine if there was a significant difference in the proportion of females to males reporting either an increase or a decrease in pain intensity. While only 3 of the 15 females (20.0\%) reported either no change or an increase in pain relative to pre-FM pain scores, $29.6 \%$ of males (8 out of 27) reported no change or an increase in pain (Table 1$)$. Chi square $\left(\chi^{2}\right)$ analysis was nonsignificant, indicating that there was no sex difference in

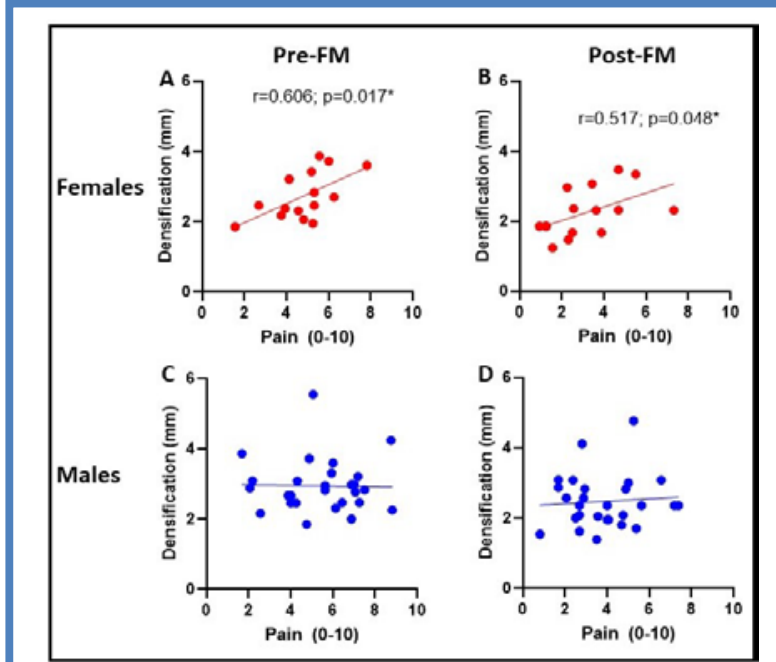

Fig 4 Densification thickness and pain ratings were significantly correlated in females (A$B$; red dots) but not males ( $C-D$; blue dots). ${ }^{*} p<0.05$.

the proportion of subjects that reported decreased versus increased pain in response to the FM intervention (Table 2). Two-way ANOVA for densification thickness indicated that sex (male/female) x time (pre-FM/postFM) comparisons yielded a significant main effect for time $(\mathrm{F}(1,40)=179.6 ; p<0.0001)$ but not sex (Table 1). Post hoc Bonferroni multiple comparisons tests showed that densification thickness for both males and females decreased significantly (Figure 3A). Specifically, females decreased from $2.73+/-0.17 \mathrm{~mm}$ to $2.25+/$ $0.18 \mathrm{~mm}$, a $17.59 \%$ reduction. Males decreased by $16.27 \%$, from $2.95+/-0.15 \mathrm{~mm}$ to $2.47+/-0.15 \mathrm{~mm}$. In terms of perceived pain, two-way ANOVA indicated that sex (male/female) x time (pre-FM/post-FM) comparisons also yielded a significant main effect for time $(F(1,40)=24.12 ; p<0.0001)$ but not sex (Table 1). Post hoc Bonferroni multiple comparisons tests showed that perceived pain for both males and females decreased significantly (Figure 3B). Specifically, females decreased from $4.81+/-0.39$ to $3.18+/-0.46$ VAS units, a $33.80 \%$ reduction in perceived pain. Males decreased by $29.36 \%$, from $5.43+/-0.38$ to $3.84+/-0.33$ VAS units. As such, no statistically significant sex-related differences were observed in terms of mean densification thickness or perceived pain scores. Considering that females are generally thought to exhibit higher sensory resolution in response to stimuli, ${ }^{31}$ we used Pearson correlation analysis to assess the relationship between palpationevoked pain intensity and densification thickness in both males and females. Interestingly, females exhibited a statistically significant positive correlation between densification thickness and pain ratings at both pre-FM and post-FM time points (Figure 4A/C, red dots, Table 1 ), whereas no statistically significant correlations were 
Table 1. Analysis parameters and results for Figures 2-4.

\begin{tabular}{|c|c|c|c|c|}
\hline $\begin{array}{l}\text { Fig- } \\
\text { ure }\end{array}$ & $\begin{array}{l}\text { Pan- } \\
\text { el }\end{array}$ & Comparison & Statistic & Result \\
\hline \multirow[t]{2}{*}{2} & $A$ & $\begin{array}{l}\text { Pre-FM densification } \\
\text { thickness vs. post FM } \\
\text { densification thickness }\end{array}$ & $\begin{array}{l}\text { T-test, paired } \\
\text { sample }\end{array}$ & $\mathrm{t}(82)=14.13 ; p<0.0001^{\star \star \star *}$ \\
\hline & B & $\begin{array}{l}\text { Pre-FM pain vs. post FM } \\
\text { pain }\end{array}$ & $\begin{array}{l}\text { T-test, paired } \\
\text { sample }\end{array}$ & $\mathrm{t}(41)=5.174 ; p<0.0001^{\star \star \star \star}$ \\
\hline \multicolumn{2}{|l|}{$\mathrm{n} / \mathrm{a}$} & $\begin{array}{l}\text { Proportion of females to } \\
\text { males reporting either an } \\
\text { increase or a decrease in } \\
\text { pain intensity }\end{array}$ & $\begin{array}{l}\text { Chi square } \\
\left(\chi^{2}\right) \text { analysis }\end{array}$ & $\chi^{2}=0.4626, p=0.4964$ \\
\hline \multirow[t]{2}{*}{3} & $A$ & $\begin{array}{l}\text { Pre-FM densification } \\
\text { thickness vs. post FM } \\
\text { densification thickness in } \\
\text { males vs. females }\end{array}$ & $\begin{array}{l}\text { Two way } \\
\text { mixed model } \\
\text { ANOVA }\end{array}$ & $\begin{array}{l}\text { Interaction (time } x \text { sex): } F(1,40)=0.008, p=0.931 \\
\text { Main effect (time) : } F(1,40)=179.6, p<0.0001^{\star \star \star \star} \\
\text { Main effect (sex) : } F(1,40)=0.889, p=0.351\end{array}$ \\
\hline & B & $\begin{array}{l}\text { Pre-FM pain vs. post FM } \\
\text { pain in males vs. females }\end{array}$ & $\begin{array}{l}\text { Two way } \\
\text { mixed model } \\
\text { ANOVA }\end{array}$ & $\begin{array}{l}\text { Interaction (time } x \text { sex): } F(1,40)=0.002, p=0.964 \\
\text { Main effect (time) : } F(1,40)=24.12, p<0.0001^{\star \star \star \star} \\
\text { Main effect (sex) : } F(1,40)=1.881, p=0.178\end{array}$ \\
\hline \multirow[t]{4}{*}{4} & $A$ & $\begin{array}{l}\text { Densification thickness } x \\
\text { pain in females, pre-FM } \\
\text { time point }\end{array}$ & $\begin{array}{l}\text { Pearson } \\
\text { correlation }\end{array}$ & $r=0.606, p=0.017^{*}$ \\
\hline & $\mathrm{B}$ & $\begin{array}{l}\text { Densification thickness } \mathrm{x} \\
\text { pain in males, pre-FM } \\
\text { time point }\end{array}$ & $\begin{array}{l}\text { Pearson } \\
\text { correlation }\end{array}$ & $r=-0.018, p=0.927$ \\
\hline & $\mathrm{C}$ & $\begin{array}{l}\text { Densification thickness } x \\
\text { pain in females, post-FM } \\
\text { time point }\end{array}$ & $\begin{array}{l}\text { Pearson } \\
\text { correlation }\end{array}$ & $r=0.517, p=0.048^{\star}$ \\
\hline & $\mathrm{D}$ & $\begin{array}{l}\text { Densification thickness } \mathrm{x} \\
\text { pain in males, post-FM } \\
\text { time point }\end{array}$ & $\begin{array}{l}\text { Pearson } \\
\text { correlation }\end{array}$ & $r=-0.081, p=0.688$ \\
\hline
\end{tabular}

found in males (Figure 4B/D, blue dots, Table 1). Raw data from all subjects is available in Table 2.

\section{Discussion}

In this pilot study, we demonstrated that pain or discomfort in self-identified somatic locations was associated with CC densifications. Moreover, we showed that both pain intensity ratings and densification thickness, measured using diagnostic ultrasound, tend to decrease after a brief FM intervention. As such, FM may be an effective means to reduce musculoskeletal pain related to fascial densifications. Given the putative role of HA in the formation of densifications, FM may also represent an effective approach for reducing the HA content, ${ }^{17}$ and HA-related increased viscosity, ${ }^{14}$ previously shown to be involved in the etiology of fascial densifications. However, larger and better controlled studies are warranted to address these questions. Overall, the identification of a beneficial therapeutic role for brief manipulation of fascial tissue on pain and associated densifications is of high clinical relevance. Importantly, our use of objective ultrasound measurements emphasizes the physiological importance of manual therapies for reducing pain intensity. We did not observe any statistically significant differences in densification thickness between males and females. In contrast with the prevailing perspectives in the literature, ${ }^{26}$ we also did not observe any statistically significant differences in pain ratings between males and females. In fact, our results show that males appeared to report slightly higher levels of pain compared to females (although not statistically significant). This is somewhat surprising given that males are often exposed to social norms espousing resistance to pain, whereas females are generally expected to show pain more readily. Indeed, males that are highly conforming to male social norms exhibit greater pain tolerance than females that are highly conforming to female social norms. ${ }^{28}$ As such, the observed similarity in mean pain intensity ratings between sexes suggests that the males in our study did 
Table2. Raw data for each subject.

\begin{tabular}{|c|c|c|c|c|c|c|c|}
\hline Location & Sex & $\begin{array}{l}\text { Densification } \\
\text { thickness } \\
\text { (Pre-FM) }\end{array}$ & $\begin{array}{l}\text { Densification } \\
\text { thickness } \\
\text { (post-FM) }\end{array}$ & $\begin{array}{l}\text { Densification } \\
\text { thickness } \\
\text { difference }\end{array}$ & $\begin{array}{l}\text { Pain } \\
\text { rating } \\
\text { (Pre-FM) }\end{array}$ & $\begin{array}{l}\text { Pain rating } \\
\text { (post-FM) }\end{array}$ & $\begin{array}{l}\text { Pain rating } \\
\text { difference }\end{array}$ \\
\hline Ankle & $\mathrm{F}$ & 1.85 & 1.47 & 0.38 & 1.5625 & 2.3125 & -0.75 \\
\hline Ankle & $M$ & 2.0 & 1.62 & 0.38 & 6.875 & 2.6875 & 4.1875 \\
\hline Ankle & M & 2.46 & 2.0 & 0.46 & 4.25 & 2.5 & 1.75 \\
\hline Ankle & M & 2.98 & 2.36 & 0.62 & 6.875 & 7.1875 & -0.3125 \\
\hline Ankle & M & 3.86 & 3.09 & 0.77 & 1.6875 & 1.6875 & 0 \\
\hline Ankle & M & 2.77 & 2.36 & 0.41 & 7.0625 & 4.0 & 3.0625 \\
\hline Ankle & $M$ & 2.98 & 2.87 & 0.11 & 7.0 & 1.6875 & 5.3125 \\
\hline Hip & M & 2.83 & 2.05 & 0.78 & 7.5 & 3.5625 & 3.9375 \\
\hline Humerus & $\mathrm{F}$ & 3.21 & 2.32 & 0.89 & 4.125 & 4.6875 & -0.5625 \\
\hline Humerus & M & 3.21 & 2.82 & 0.39 & 7.1875 & 4.875 & 2.3125 \\
\hline Knee & $\mathrm{F}$ & 3.6 & 3.34 & 0.26 & 7.8125 & 5.5 & 2.3125 \\
\hline Knee & $\mathrm{M}$ & 4.24 & 4.11 & 0.13 & 8.75 & 2.8125 & 5.9375 \\
\hline Knee & M & 5.55 & 4.77 & 0.78 & 5.0625 & 5.25 & -0.1875 \\
\hline Knee & M & 1.85 & 1.39 & 0.46 & 4.75 & 3.5 & 1.25 \\
\hline lumbi & $\mathrm{F}$ & 2.7 & 2.31 & 0.39 & 6.25 & 7.3125 & -1.0625 \\
\hline lumbi & $\mathrm{F}$ & 2.06 & 1.85 & 0.21 & 4.8125 & 1.25 & 3.5625 \\
\hline lumbi & $\mathrm{F}$ & 3.86 & 2.96 & 0.9 & 5.5625 & 2.25 & 3.3125 \\
\hline lumbi & M & 2.88 & 2.36 & 0.52 & 2.0625 & 2.6875 & -0.625 \\
\hline lumbi & $\mathrm{M}$ & 2.47 & 2.08 & 0.39 & 6.4375 & 4.75 & 1.6875 \\
\hline lumbi & $\mathrm{M}$ & 3.6 & 3.08 & 0.52 & 6.0 & 6.5625 & -0.5625 \\
\hline Neck & $\mathrm{F}$ & 1.95 & 1.24 & 0.71 & 5.25 & 1.5625 & 3.6875 \\
\hline Pelvis & $F$ & 3.42 & 3.06 & 0.36 & 5.1875 & 3.4375 & 1.75 \\
\hline Pelvis & $\mathrm{F}$ & 3.72 & 3.47 & 0.25 & 6.0 & 4.6875 & 1.3125 \\
\hline Pelvis & M & 3.08 & 2.57 & 0.51 & 4.3125 & 2.0625 & 2.25 \\
\hline Pelvis & $\mathrm{M}$ & 2.67 & 2.36 & 0.31 & 4.0 & 7.375 & -3.375 \\
\hline Pelvis & M & 3.09 & 2.57 & 0.52 & 2.1875 & 2.875 & -0.6875 \\
\hline Scapula & $\mathrm{F}$ & 2.31 & 1.67 & 0.64 & 4.5625 & 3.875 & 0.6875 \\
\hline Scapula & $\mathrm{F}$ & 2.83 & 2.31 & 0.52 & 5.3125 & 3.625 & 1.6875 \\
\hline Scapula & $\mathrm{F}$ & 2.46 & 2.36 & 0.1 & 2.6875 & 2.5625 & 0.125 \\
\hline Scapula & $\mathrm{M}$ & 2.47 & 1.95 & 0.52 & 7.25 & 4.0625 & 3.1875 \\
\hline Scapula & $M$ & 2.26 & 1.95 & 0.31 & 8.8125 & 4.0 & 4.8125 \\
\hline Scapula & M & 2.95 & 2.83 & 0.12 & 5.625 & 2.9375 & 2.6875 \\
\hline Scapula & $\mathrm{M}$ & 2.31 & 1.7 & 0.61 & 6.125 & 5.375 & 0.75 \\
\hline Scapula & M & 3.72 & 3.08 & 0.64 & 4.875 & 2.375 & 2.5 \\
\hline Scapula & $\mathrm{M}$ & 2.46 & 2.08 & 0.38 & 4.0 & 2.6875 & 1.3125 \\
\hline Scapula & $\mathrm{M}$ & 3.31 & 3.0 & 0.31 & 5.9375 & 5.0 & 0.9375 \\
\hline Thorax & $\mathrm{F}$ & 2.38 & 1.85 & 0.53 & 3.9375 & 1.25 & 2.6875 \\
\hline Thorax & $\mathrm{M}$ & 2.67 & 2.36 & 0.31 & 3.875 & 5.625 & -1.75 \\
\hline Thorax & $M$ & 2.16 & 1.54 & 0.62 & 2.5625 & 0.8125 & 1.75 \\
\hline Wrist & $\mathrm{F}$ & 2.46 & 1.85 & 0.61 & 5.3125 & 0.9375 & 4.375 \\
\hline Wrist & $F$ & 2.18 & 1.67 & 0.51 & 3.75 & 2.5 & 1.25 \\
\hline Wrist & M & 2.82 & 1.8 & 1.02 & 5.625 & 4.6875 & 0.9375 \\
\hline
\end{tabular}


is possible that this effect is due to study participants being a convenience sample comprised mainly of chiropractic students in which socially normative perspectives were subordinated by the clinical training environment where the study took place. Interestingly, we did find that pain intensity ratings were significantly associated with densification thickness at both pre-FM and post-FM time points in females only. Indeed, it is well known that females are more likely to report a greater variety of symptoms more frequently and with greater intensity than males, with potential etiological factors including intrinsic biological differences as well as psychosocial and sensory appraisal differences, as reviewed in Barsky et al. ${ }^{29}$ While our measures do not permit any speculation about the potential biological underpinnings of our findings, the significant correlation between pain intensity and densification thickness that was apparent only in females may indicate sex differences in sensory discrimination and/or appraisal of painful stimuli. Indeed, while the literature indicates that females seem to be more sensitive to painful stimuli, ${ }^{26}$ they are also more aware of and/or attentive to painful stimuli than males, ${ }^{30}$ as well as being better able to distinguish between two points in the two-point discrimination task. ${ }^{31}$ As such, the effect we are reporting may represent the nociceptive equivalent of the wellknown phenomenon of greater sensory discrimination in females compared to males. In other words, females' perceived pain intensity may be more closely aligned with the magnitude of the painful stimulus than males, reflecting a novel perspective on the broad literature on sex differences in pain sensitivity. A potential mechanism supporting this could be differential innervation of fascial tissue in females compared to males, such that thicker densifications produce greater nociceptive input upon palpation in females. However, to our knowledge, there is no evidence in the literature of sex differences in fascial innervation.

As a limitation of this study, it should be noted that the intention of this study was not to assess the effectiveness of FM on severe acute or chronic pain, but instead to serve as a pilot study to evaluate a potential role for CC densifications in common self-reported pain/stiffness across various somatic locations, and to determine the effects of brief FM on these relatively low-level somatic complaints as well as ultrasound-detected densifications. Importantly, while we consistently observed densifications in somatic regions identified as painful by the study subjects, we did not determine if densifications occur in other, non-painful regions. As such, we cannot state that all densifications are painful or that all painful somatic regions contain densifications. Moreover, the sample was of convenience, comprised mainly of chiropractic students. As such, these findings should not be generalized to other populations, including clinical pain populations. This study also involved a relatively small sample size ( $n=15$ females $+n=27$ males) that limits the ability to generalize to a broader population. In the same vein, our study was underpowered to detect any potential differences in perceived pain sensitivity associated with densifications across somatic regions. Future studies may focus on densifications located in specific somatic regions such as the cervical, thoracic and lumbar regions of the back. From a technical standpoint, while ultrasonography represents a powerful imaging technique for visualizing organs, tissues and other structures within the body, it is not optimal for pretest/post-test experimental designs due to probe placement challenges and movement of internal tissues/organs. While we made every effort to accurately position the probe for post-test measurements, it is likely that there was some variability between pre- and posttest. Nonetheless, the consistent decrease in densification thickness we recorded suggests that our measurements were relatively accurate. Another potential limitation involves the lack of control group with sham intervention. As such, we cannot state categorically that the FM intervention caused a reduction in densification thickness or perceived pain. On the other hand, while a sham intervention may be reasonably expected to evoke a placebo-related reduced pain response, it is unlikely that a sham intervention could impact densification thickness. As such, we feel that our findings represent a potentially exciting avenue for the treatment of pain.

In conclusion, using diagnostic ultrasound approaches, we demonstrated that there is increased thickness of the loose connective tissue portion of the fascia in a painful densification, a finding that supports the perspectives of other groups. ${ }^{10,24}$ We showed that these densifications in the loose connective tissue can be decreased following Fascial Manipulation ${ }^{\circledR}$ (Stecco method). Together, these results support the hypothesis that densifications in fascia reflect localized thickening of the loose connective tissue elements, and that FM is a viable and effective treatment option to decrease pain. In addition to this, we demonstrated that females appear to be better able to resolve subtle differences in pain intensity following palpation of a densification, compared to males, thus supporting the hypothesis that females are better able to perceive the magnitude of noxious sensory input.

\section{List of acronyms}

FM - Fascial manipulation

\section{Contributions of Authors}

EH designed the study, collected the data, interpreted the data and edited the manuscript; JMK operated the ultrasound machine; RSL collected data, analysis of data KM provided administrative assistance, managed subject intake and paperwork; TF analyzed/interpreted the data and edited the manuscript; MHP analyzed/interpreted the data and drafted the manuscript.

\section{Acknowledgments}

The authors hereby thank the patients and volunteers, who aided in conducting the present study. 


\section{Funding}

This research did not receive grant support from funding agencies in the public, commercial, or not-for-profit sectors.

\section{Data Availability Statement}

The data set associated with the findings described in this manuscript is provided as a supplemental table in this manuscript.

\section{Conflict of Interest}

The authors report no conflict of interest.

\section{Ethical Publication Statement}

We confirm that we have read the Journal's position on issues involved in ethical publication and affirm that this report is consistent with those guidelines.

\section{Corresponding Author}

Emmett Hughes, DC, 57 Southdown Road, Huntington, NY 11743, USA

Phone 001 631-988-6445

E-mail: ehughes@bridgeport.edu

\section{E-mails and ORCID iD of co-authors}

Jessica M. Koenig: jessicakoenig@optonline.net Robert S. Lee: wellintegrativecare@gmail.com Kena McDermott: mcdermottkena@gmail.com Tina Freilicher: tfreilic@bridgeport.edu Mark H. Pitcher: mark.pitcher@nih.gov

\section{References}

1. Harper B, Steinbeck L, Aron A. Fascial manipulation vs. standard physical therapy practice for low back pain diagnoses: A pragmatic study. J Bodyw Mov Ther. 2019. 23(1):115-121. doi: 10.1016/j.jbmt.2018.10.007.

2. Raghavan P, Lu Y, Mirchandani M, Stecco A Human Recombinant Hyaluronidase Injections For Upper Limb Muscle Stiffness in Individuals With Cerebral Injury: A Case Series. EBioMedicine. 2016. 9:306-313. doi: 10.1016/j.ebiom.2016.05.014.

3. Rajasekar S, Marchand AM. Fascial Manipulation for persistent knee pain following ACL and meniscus repair. J Bodyw Mov Ther. 2017. 21(2):452-458. doi: 10.1016/j.jbmt.2016.08.014.

4. Stecco A, Stern R, Fantoni I, De Caro R, Stecco C. Fascial Disorders: Implications for Treatment. PM R. $2016 . \quad 8(2): 161-8 . \quad$ doi: 10.1016/j.pmrj.2015.06.006.

5. Findley T.W., Schleip R (Ed.), Fascia Research: Basic Science and Implications for Conventional and Complementary Health Care, Elsevier, Munich (2007).

6. Adstrum S, Hedley G, Schleip R, Stecco C, Yucesoy CA Defining the fascial system. J Bodyw
Mov Ther. 2017. 21(1):173-177. doi: 10.1016/j.jbmt.2016.11.003.

7. Morley J, Fan C, McDermott K, Fede C, Hughes E, Stecco C. The crural interosseous membrane revisited: a histological and microscopic study. Eur J Transl Myol. 2019. 9;29(3):8340. doi: 10.4081/ejtm.2019.8340.

8. Sakada S. Mechanoreceptors in fascia, periosteum and periodontal ligament. Bull Tokyo Med Dent Univ. 1974. 21 Suppl(0):11-3.

9. Paoletti S. The Fasciae: Anatomy, Dysfunction and Treatment. 2006. Eastland Press, Seattle, WA.

10. Pavan PG, Stecco A, Stern R, Stecco C. Painful connections: densification versus fibrosis of fascia. Curr Pain Headache Rep. 2014;18(8):441. doi: 10.1007/s11916-014-0441-4

11. Chaitow L. Somatic dysfunction and fascia's gliding-potential. J Bodyw Mov Ther. 2014. 18(1):1-3. doi: 10.1016/j.jbmt.2013.11.019.

12. Raja $P$, Bhat $S$, Fernández-de-las-Peñas C, Gangavelli R, David F, Shankar R, Prabhu A. Effectiveness of deep cervical fascial manipulation and yoga postures on pain, function, and oculomotor control in patients with mechanical neck pain: study protocol of a pragmatic, parallelgroup, randomized, controlled trialTrials. 2021. 22:574. Doi: 10.1186/s13063-021-05533-w

13. Pratt RL. Hyaluronan and the fascial frontier. Int. J. Mol. Sci. 2021. 22, 6845. doi:10.3390/ijms22136845

14. Cowman MK, Schmidt TA, Raghavan P, Stecoo A. Viscoelastic Properties of Hyaluronan in Physiological Conditions. F100Res. 2015. 4:622. doi: 10.12688/f1000research.6885.1.

15. Fede C, Angelini A, Stern R, Macchi V, Porzionato A, Ruggieri P, De Caro R, Stecco C. Quantification of hyaluronan in human fasciae: variations with function and anatomical site. J Anat. 2018. 233(4):552-556.

16. Stecco C, Stern R, Porzionato A, Macchi V, Masiero S, Stecco A, De Caro R. Hyaluronan within fascia in the etiology of myofascial pain. Surg Radiol Anat. 2011. 33:891-896. DOI 10.1007/s00276-011-0876-9

17. Hughes E, McDermott K, Funk M. Evaluation of hyaluronan content in areas of densification compared to adjacent areas of fascia. JBMT. 2019. 23(2):324-328. doi.org/10.1016/j.jbmt.2019.01.017

18. Day JA, Stecco C, Stecco A. Application of Fascial Manipulation technique in chronic shoulder painanatomical basis and clinical implications. J Bodyw Mov Ther. 2009. 13(2):128-35. doi: 10.1016/j.jbmt.2008.04.044.

19. Branchini M, Lopopolo F, Andreoli E, Loreti I, Marchand AM, Stecco A. Fascial Manipulation for chronic aspecific low back pain: a single blinded randomized controlled trial. F1000Res. 2015. 4:1208. doi: 10.12688/f1000research.6890.2. 
20. Casato G, Stecco C, Busin R. Eur J Transl Myol. Role of fasciae in nonspecific low back pain. 2019. 29(3):8330. doi: 10.4081/ejtm.2019.8330.

21. Menon RG, Oswald SF, Raghavan P, Regatte RR, Stecco A. T(1rho)-Mapping for Musculoskeletal Pain Diagnosis: Case Series of Variation of Water Bound Glycosaminoglycans Quantification before and after Fascial Manipulation ${ }^{\circledR}$ in Subjects with Elbow Pain. Int J Environ Res Public Health. 2020 Jan 22;17(3):708. doi: 10.3390/ijerph17030708.

22. Guarda-Nardini L, Stecco A, Stecco C, Masiero S, Manfredini D. Myofascial pain of the jaw muscles: comparison of short-term effectiveness of botulinum toxin injections and fascial manipulation technique. Cranio. 2012. 30(2):95-102. doi: 10.1179/crn.2012.014.

23. Maetzler M, Ruescher M, Punzenberger F, Wang W, Abboud RJ. Progressive rehabilitation of the sprained ankle: A novel treatment method. Foot (Edinb). 2020. 43:101645. doi: 10.1016/j.foot.2019.09.007.

24. Luomala T, Pihlman M, Heiskanen J, Stecco C. Case study: Could ultrasound and elastography visualized densified areas inside the deep fascia? J Bodyw Mov Ther. 2014. 18(3):462-8. doi: 10.1016/j.jbmt.2013.11.020.

25. Fidut-Wrońska J, Chołuj K, Chmiel J, PiktoPitkiewicz K, Majcher P. Observation using thermography of post-operative reaction after fascial manipulation ${ }^{\circledR}$. Ann Agric Environ Med. 2019. 26(3):468-471. doi: 10.26444/aaem/103456.
26. Bartley EJ, Fillingim RB. Sex differences in pain: a brief review of clinical and experimental findings. Brit J Anaesth. 2013. 111 (1): 52-8. doi:10.1093/bja/aet127

27. Fillingim RB. Individual Differences in Pain: Understanding the Mosaic that Makes Pain Personal. Pain. 2017. 158(Suppl 1): S11-S18. doi:10.1097/j.pain.0000000000000775.

28. Pool GJ, Schwegler AF, Theodore BR, Fuchs PN. Role of gender norms and group identification on hypothetical and experimental pain tolerance. Pain. 2017. 129(1):122-129.

29. Barsky AJ, Peekna HM, Borus JF. Somatic symptom reporting in women and men. J Gen Intern Med. 2001. 16:266-275. DOI: 10.1046/j.15251497.2001.00229.x

30. Straube T, Schmidt S, Weiss T, Mentzel HJ, Miltner WHR. Sex Differences in Brain Activation to Anticipated and Experienced Pain in the Medial Prefrontal Cortex. 2009. Human Brain Mapping 30:689-698.

31. Won SY, Kim HK, Kim ME, Kim KS. Two-point discrimination values vary depending on test site, sex and test modality in the orofacial region: a preliminary study. J Appl Oral Sci. 2017. 25(4):427-435. doi: 10.1590/1678-7757-20160462 .

Submission: January 18, 2022

Revision received: February 22, 2022 Accepted for publication: February 22, 2022 